\title{
Researches regarding the active and passive monitoring of aeromicroflora in milling and bread manufacturing
}

\author{
GHEORGHE PUCHIANU ${ }^{1}$, VALENTIN NECULA ${ }^{1}$, DORIN VALTER ENACHE ${ }^{1}$, \\ MIHAI DANEŞ ${ }^{2}$, MIRABELA LUPU ${ }^{1}$
}

\footnotetext{
${ }^{1}$ Transilvania University of Brasov, Faculty of Food and Tourism, Bd. Eroilor nr. 29, 500036, Brasov, Romania

${ }^{2}$ University of Agronomic Sciences and Veterinary Medicine Bucharest, 59 Mărăşti Boulevard, District 1, 011464, Bucharest, Romania
}

\begin{abstract}
In the spaces of milling and bread manufacture units, air contaminations are produced with microorganisms which come from the microflora of the used raw materials, but also from the residual microflora resulted after the prior processes of processing, reason for which the monitoring of aeromicroflora from such units offer important indices, representing the decisional basis of implementing the corrective measures.

To do this thing, we proceeded to the sampling using methodologies of active and passive monitoring. The microbiological examinations performed were: evaluation of total number of germs (TGN) of air contaminants $/ \mathrm{m}^{3}$ of air and the number of yeasts and molds $/ \mathrm{m}^{3}$ of air $(\mathrm{Y}+\mathrm{M})$.

For the monitoring we used two procedures of air sampling: the method of sedimentation by the exposure of Petri plates with solid environment of culture with the purpose of collecting particles which are deposited by the gravity and sampling of some defined quantities of air passed through a sampling device, directly on a solid culture medium.

After using the two methods, we concluded that the passive monitoring of aeromicroflora permitted the detection of a number of out of line samples contained between $9 \%$ (TGN) and $13 \%(\mathrm{Y}+\mathrm{M})$, and the active monitoring of a number contained between $12 \%$ (TGN) and $18 \%(\mathrm{Y}+\mathrm{M})$. The most unconforming were registered in the spaces intended for the receipt of raw materials and grinding of cereals.
\end{abstract}

Keywords Microaeroflora, passive and active monitoring, total number of germs, yeast and mold.

To cite this article: PUCHIANU G, NECULA V, ENACHE DV, DANEŞ M, LUPU M. Researches regarding the active and passive monitoring of aeromicroflora in milling and bread manufacturing. Rom Biotechnol Lett. 2020; 25(2): 1465-1472. DOI: $10.25083 / \mathrm{rbl} / 25.2 / 1465.1472$

*Corresponding author: GHEORGHE PUCHIANU, Transilvania University of Brasov, Faculty of Food and Tourism, Bd. Eroilor nr. 29, 500036, Tel.: +40-(268) 41.30.00, Fax: +40-(268) 41.05.25, Brasov, Romania E-mail: gpuchianu@yahoo.com 


\section{Introduction}

The main raw materials used in the industry of milling are the corn and rye which are obtained from the flour necessary to manufacture the bread and the flour products, but as weight, the corn occupies the first place in milling. The most known species are the common corn, with the biggest use in making bread bakery and hard corn, used to obtain the flour with special destination for the production of pasta.

The cereal grains are contaminated, especially, with bacteria and mold which can influence their technological, agrotechnical and sanitary quality.

The most wide spread bacteria on the cereal grain surface belong to the types: Acetobacter, Flavobacterium, Micrococcus, Pseudomonas, Pediococcus, Streptococcus, Lactobcillus, Leuconostoc, Escherichia, Enterobacter, Klebsiela, Proteus, Bacillus, Clostridium, Actinomyces, Corinebacterium, Brevibacterium, and the sediments and molds involved in contamination most frequently are: Alternaria, Cladosporium, Aspergillus, Trichoderma, Fusarium, Penicillium, Sacharomyces, Pichia, Seratia, Helmitosporium, Geotrichum, Claviceps, Ustillago, Tilettia, Penicillium [1].

In the processing spaces are produced contaminations of air with microorganisms which come from the microflora of the used raw materials, but also from the residual microflora used after the prior processes of processing. A humidity bigger than $60 \%$, combined with a high temperature, favor the development and multiplication of microorganisms and such a possible contamination of products, and of the personnel which perform their activity on various stages of the technological process, about $10 \%$ presenting allergies of fungal type $[3,5,9]$.

The microbial contamination degree of air and surfaces in the processing units, reflect a potential risk of sickness for a human being, but also by contamination for food, which increases pro rata with their density and with the presence of the potential pathogenic or pathogenic species [15].

For this reason, it is necessary to perform a monitoring of the aeromicroflora from the milling and bread manufacturing units, to know the degree of contamination of the air and involved microorganisms species, in order to establish the action methods [10].

The microbiologic control of air addresses to the work spaces of the milling and bread manufacturing units, during the main stages of the technological process, which, mainly, includes: the quantitative and qualitative receipt, the storage of cereals, their preparation for grinding, the conditioning of cereals, the cereals grinding, screening, homogenization, storage and palletization, storage and delivery.

There are two main means of monitoring the microaeroflora in the milling and bread manufacturing units: passive monitoring by sedimentation and active monitoring by suction. Both have the same level of importance, becoming now an essential instrument for monitoring the environment in the food sector [2].
The sedimentation method is adequate to detect microbial particles which are deposited passively, due to the gravity. For the passive monitoring, two methods can be used: sedimentation method, according to the Polish standard PN 89/Z-04008/08 and the Barzoi method [4].

The sedimentation disadvantages are: the method is non - volumetric (does not offer information on the volume of air from which the particles are collected), not allowing a precise quantitative determination, the applicability of the plates is restricted, can monitor only viable biological particles which sediment from air and are deposited on a surface in a certain exposure time, cannot detect small hanged up particles from the air, are influenced by the interference and contamination from other sources, the agar from the plates can be damaged in the case of too long exposure, the plates can become very loaded in strong contaminated environments and the data interpretation becomes difficult [4].

The advantages of sedimentation are: plates are cheap, easy to use and do not need special equipment. They are used more for the qualitative analysis of microaeroflora, the provided data can detect the tendencies and can offer and early warning on the problems. In an environment with low risk, the plates can offer an adequate mean of microbiological monitoring of the air quality [4].

The suction method can be performed by: impact, according to ISO 16000-18 - adequate for the cases in which are expected only low microbial concentrations, for example, clean spaces, installations of food production, etc.; filtration, according to ISO 16000-16 - adequate for very contaminated environments, in which the impact technique can determine the overloading of the plate. The method allows the use of decimal dilutions to determine a real number of microorganisms [11].

There is an active, volumetric method (offer information on the air volume from which particles are collected) and therefore, allows the precise quantitative determination, needing the use of an equipment which absorbs a known volume of air.

There are two types of sampling devices available commercially: with slot and with separator. In the devices with slot, the air is pulled by a tight slot and the particles are deposited on a plate with agar found in rotation. In the devices with separator, the air is pulled by a punctured plate (separator) with holes, with the known diameter and the particles are deposited on a plate with agar fixed underneath. There is the possibility to group more separators with various dimensions.

For the method by filtration, the filter membrane obtained after sampling are hanged up again in $5 \mathrm{ml}$ of physiological serum with $0,01 \%$ polysorbate 80 (tween), this representing the initial suspension, from which it is prepared decimal dilutions. $0,1 \mathrm{ml}$ of these dilutions are dispersed on the plates with agar surfaces [12].

Whether the sampling procedure (by impact or filtration), the number of germs is calculated reporting the number of cultures developed on the surface of the culture environment to the air volume. The calculation method for the two methods is provided in the ISO 16000-17 standard [11]. 


\section{Materials and Methods}

The diagnostic method was performed in accordance with the provisions of SR EN ISO 4833-1/2009 - horizontal method for listing microorganisms, part 1 , the count technique of cultures at $30^{\circ} \mathrm{C}$ and SR ISO 21527-2:2009, the horizontal method for the count of sediments and molds, part 2, the count technique of cultures in products with a water activity smaller or equal with $0,95[13,14]$.

The diagnostic equipment and materials used to perform the diagnostic were: oven, incubator $\left(25^{\circ} \pm 1^{\circ} \mathrm{C}\right)$, incubator $\left(37^{\circ} \pm 1^{\circ} \mathrm{C}\right)$, water bath $\left(45^{\circ} \pm 1^{\circ} \mathrm{C}\right)$, protection cabinet with laminar flow, equipment to count the cultures, $\mathrm{pH}-$ meter with precision of 0,1 units of $\mathrm{pH}$ at $25^{\circ} \mathrm{C}$, microscope, gas fire, Petri plates with the diameter of 90-100 mm, disposable, device for sampling air samples;

To perform the passive monitoring we used standard Petri plates, containing culture medium, Plate Count Agar (PCA) and Dichloran Glycerol (DG18), which after opening we exposed in controlling rooms, 2 plates for total number of germs and 2 plates for sediment and molds, for 10 minutes.

The plates were placed in work rooms at the level of the work surfaces - a plate on floor and a plate on a height of $0,8-1,0 \mathrm{~m}$, with the purpose of collecting particles which sediments by their gravity. After 10 minutes the plates were covered with their top and they were sent immediately to the laboratory.

To perform the active monitoring we sampled a defined quantity of air after passing through a sampling device, the air particles being collected directly on a solid culture medium, using devices with separator, which allow that the air is pulled through a perforated plate (separator) with holes, with a known diameter and the particles are deposited on a plated with agar fixed underneath.

After sampling the plates were identified depending on the sampling place, packed, sealed and delivered in conditions of cooling $\left(4-8^{\circ} \mathrm{C}\right)$ to the laboratory, where they were incubated immediately after the arrival at various temperatures, depending on the targeted organism (TGN or $\mathrm{Y}+\mathrm{M})$. The samples were introduced in the Atlas Vet LIMS system, intended for the full management of the laboratory activity.

\section{Results and Discussion}

The samples were sampled from various work spaces of two milling and bread manufacturing units across Brasov County. The total number of samples was of 158 by the sedimentation method and 50 by the suction method.

By the sedimentation technique, the samples were taken from the following work spaces: Table 1.

Table 1. The number of samples taken by sedimentation

\begin{tabular}{|c|c|c|c|c|c|c|c|}
\hline \multirow[t]{2}{*}{ No. } & \multirow{2}{*}{$\begin{array}{c}\text { The name of } \\
\text { the unit }\end{array}$} & \multirow{2}{*}{$\begin{array}{c}\text { Total } \\
\text { number of } \\
\text { samples }\end{array}$} & \multicolumn{5}{|c|}{ Denomination of space } \\
\hline & & & $\begin{array}{l}\text { Receipt of raw } \\
\text { materials }\end{array}$ & Storage & Milling & Packaging & $\begin{array}{c}\text { Storing and } \\
\text { delivery }\end{array}$ \\
\hline 1. & $\mathrm{~A}$ & 74 & 18 & 16 & 16 & 12 & 12 \\
\hline 2. & $\mathrm{~B}$ & 84 & 20 & 18 & 18 & 14 & 14 \\
\hline & Total & 158 & 38 & 34 & 34 & 26 & 26 \\
\hline
\end{tabular}

To sample air samples, we used standard Petri plates, containing culture medium - PCA for Total Number of Germs (TGN) and DG18 for Y+M. The culture medium were prepared according to the instruction and then they were casted in Petri plates with a diameter of $9 \mathrm{~cm}$. Subsequently, the 4 Petri plates ( 2 for TGN and 2 for $\mathrm{Y}+\mathrm{M}$ ), were positioned in the spaces mentioned at Table 1 on a surface of $1 \mathrm{~m}^{2}$ on the floor and on other surfaces placed at different heights in relation with it (1-2 m), for 15 minutes.
After the expiration of the contact time, the Petri plates were covered and delivered immediately to the laboratory, where they were incubated at a temperature of $37^{\circ} \mathrm{C}$ in the case of TGN and $25^{\circ} \mathrm{C}$ in the case of $\mathrm{Y}+\mathrm{M}$. The incubation period was of 72 hours in the case of TGN and 4-5 days in the case of Y+M. After incubation the culture medium were examined to identify the eventual development cultures (Fig. 1, 2, 3, 4).
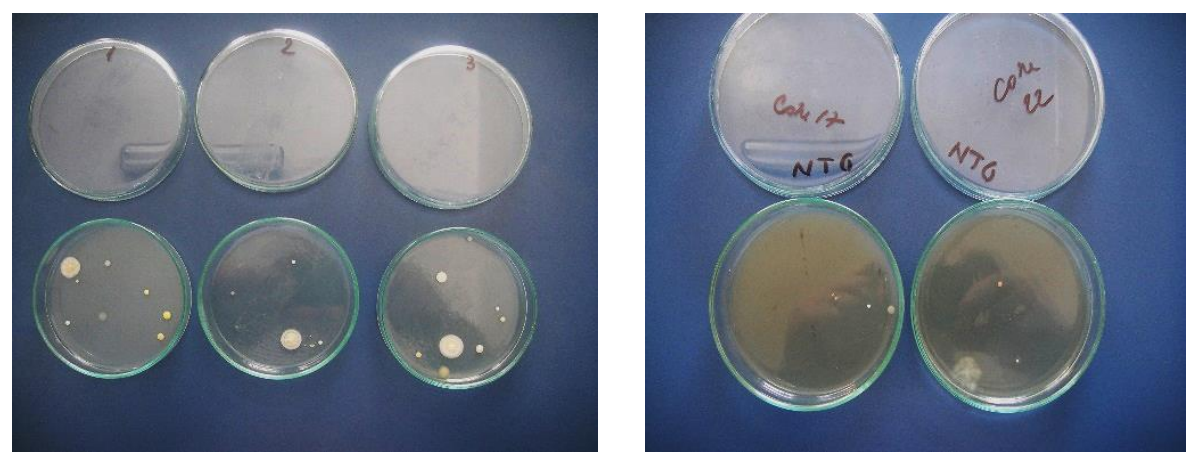

Figure 1, 2. Petri plates with PCA - CFU environment 

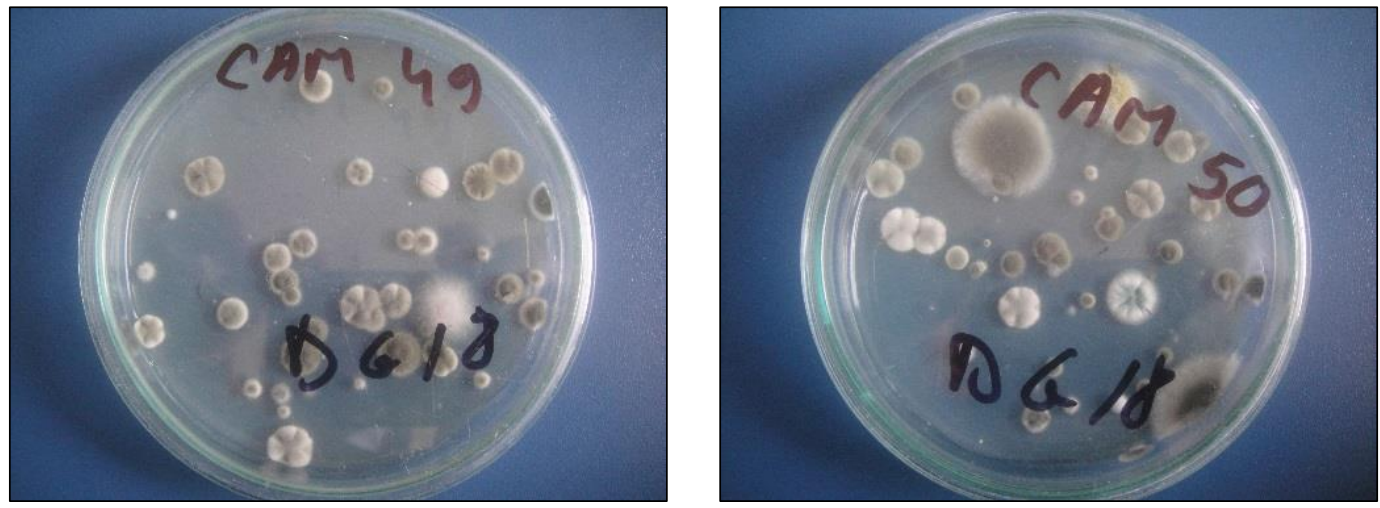

Figure 3, 4. Petri plates with DG 18 - Y+M environment

Depending on the targeted organism (TGN or $\mathrm{Y}+\mathrm{M})$, we determined the microbiological loading of air by estimating the number of microorganisms expressed as $\mathrm{cfu} / \mathrm{m}^{3}$.

For the calculation we used 3 formulas: Polish standard PN 89/Z-04008/08, formula Omelianski and Barzoi method, as it follows:

1. Polish standard PN 89/Z-04008/08:

$$
c f u / m^{3} \text { air }=a \cdot 10.000 / p \cdot t \cdot 0.2
$$

where:

$\mathrm{a}=$ the number of cultures from the Petri plate

$\mathrm{p}=$ surface of the Petri plate in $\mathrm{cm}^{2}$ (for a diameter of $9 \mathrm{~cm}$, $\mathrm{S}=3.14 \times \mathrm{R}^{2}=63.5 \mathrm{~cm}^{2}$ )

$t=$ the exposure time of the Petri plate
2. Omelianski formula:

$$
c f u / m^{3} \text { air }=N \times 10.000 / S \times K
$$

where:

$\mathrm{N}=$ the number of cultures from the Petri plate

$\mathrm{S}=$ surface of the Petri plate in $\mathrm{cm}^{2}$ (for a diameter of $9 \mathrm{~cm}$, $\mathrm{S}=3.14 \times \mathrm{R}^{2}=63.5 \mathrm{~cm}^{2}$ )

$\mathrm{K}=$ coefficient of exposure time (factor) $(5$ minutes $=1$; 10 minutes $=2 ; 15$ minutes $=3$ )

3. Barzoi method:

$$
c f u / m^{3} \text { air }=n \times 50
$$

where:

$\mathrm{n}=$ the average of the number of culture from the 2 Petri plates

For this method are used 2 Petri plates with a diameter of $10 \mathrm{~cm}$, which are exposed for 10 minutes.

\begin{tabular}{|c|c|c|c|c|c|c|c|c|c|c|c|c|c|c|c|c|c|c|}
\hline \multirow{4}{*}{$\begin{array}{l}\text { The } \\
\text { name of } \\
\text { the unit }\end{array}$} & \multirow{2}{*}{\multicolumn{3}{|c|}{$\begin{array}{c}\text { Total number } \\
\text { of samples }\end{array}$}} & \multicolumn{15}{|c|}{ Denomination of space } \\
\hline & & & & \multicolumn{3}{|c|}{$\begin{array}{c}\text { Receipt of raw } \\
\text { materials }\end{array}$} & \multicolumn{3}{|c|}{ Storage } & \multicolumn{3}{|c|}{ Milling } & \multicolumn{3}{|c|}{ Packaging } & \multicolumn{3}{|c|}{$\begin{array}{c}\text { Storing and } \\
\text { delivery }\end{array}$} \\
\hline & $\mathrm{C}$ & \multicolumn{2}{|c|}{$\mathrm{U}$} & $\mathrm{C}$ & \multicolumn{2}{|c|}{$\mathrm{U}$} & $\mathrm{C}$ & \multicolumn{2}{|c|}{$\mathrm{U}$} & $\mathrm{C}$ & \multicolumn{2}{|c|}{$\mathrm{U}$} & $\mathrm{C}$ & \multicolumn{2}{|c|}{$\mathrm{U}$} & $\mathrm{C}$ & \multicolumn{2}{|c|}{$\mathrm{U}$} \\
\hline & No & No & $\%$ & No & No & $\%$ & No & No & $\%$ & No & No & $\%$ & No & No & $\%$ & No & No & $\%$ \\
\hline A & 69 & 5 & 11 & 16 & 2 & 11 & 15 & 1 & 6 & 14 & 2 & 13 & 12 & - & - & 12 & - & - \\
\hline B & 74 & 10 & 12 & 17 & 3 & 15 & 17 & 1 & 6 & 14 & 4 & 22 & 13 & 1 & 7 & 13 & 1 & 7 \\
\hline Total & 143 & 15 & 9 & 33 & 5 & 13 & 32 & 2 & 6 & 28 & 6 & 18 & 25 & 1 & 4 & 25 & 1 & 4 \\
\hline
\end{tabular}

In the TGN case, the results were the following: Table 2.

Table 2. Number of conform (C) and unconform samples (U)

$\mathrm{C}=$ conform

$\mathrm{N}=$ unconform 
In the $\mathrm{Y}+\mathrm{M}$ cases, the results were the following: Table 3.

Table 3. Number of conform (C) and unconform samples (U)

\begin{tabular}{|c|c|c|c|c|c|c|c|c|c|c|c|c|c|c|c|c|c|c|}
\hline \multirow{4}{*}{$\begin{array}{l}\text { The name } \\
\text { of the unit }\end{array}$} & \multirow{2}{*}{\multicolumn{3}{|c|}{$\begin{array}{l}\text { Total number of } \\
\text { samples }\end{array}$}} & \multicolumn{15}{|c|}{ Denomination of space } \\
\hline & & & & \multicolumn{3}{|c|}{$\begin{array}{c}\text { Receipt of raw } \\
\text { materials }\end{array}$} & \multicolumn{3}{|c|}{ Storage } & \multicolumn{3}{|c|}{ Milling } & \multicolumn{3}{|c|}{ Packaging } & \multicolumn{3}{|c|}{$\begin{array}{c}\text { Storing and } \\
\text { delivery }\end{array}$} \\
\hline & \multirow{2}{*}{$\begin{array}{c}\mathrm{C} \\
\mathrm{No} \\
\end{array}$} & \multicolumn{2}{|c|}{$\mathrm{U}$} & $\mathrm{C}$ & \multicolumn{2}{|c|}{$\mathrm{U}$} & \multirow{2}{*}{$\begin{array}{c}\mathrm{C} \\
\mathrm{No} \\
\end{array}$} & \multicolumn{2}{|c|}{$\mathrm{U}$} & \multirow{2}{*}{$\begin{array}{c}\mathrm{C} \\
\mathrm{No} \\
\end{array}$} & \multicolumn{2}{|c|}{$\mathrm{U}$} & \multirow{2}{*}{$\begin{array}{c}\mathrm{C} \\
\mathrm{No} \\
\end{array}$} & \multicolumn{2}{|c|}{$\mathrm{U}$} & \multirow{2}{*}{$\begin{array}{c}\mathrm{C} \\
\mathrm{No} \\
\end{array}$} & \multicolumn{2}{|c|}{$\mathrm{U}$} \\
\hline & & No & $\%$ & No & No & $\%$ & & No & $\%$ & & No & $\%$ & & No & $\%$ & & No & $\%$ \\
\hline $\mathrm{A}$ & 66 & 8 & 11 & 15 & 3 & 17 & 15 & 1 & 6 & 13 & 3 & 19 & 11 & 1 & 8 & 12 & - & - \\
\hline B & 71 & 13 & 15 & 16 & 4 & 20 & 16 & 2 & 11 & 14 & 4 & 22 & 12 & 2 & 14 & 13 & 1 & 7 \\
\hline Total & 137 & 21 & 13 & 31 & 7 & 18 & 31 & 3 & 9 & 27 & 7 & 21 & 23 & 3 & 12 & 25 & 1 & 4 \\
\hline
\end{tabular}

The results indicate that in the case of monitoring the aeromicroflora by the method of sedimentation, a number of 15 samples, representing a percentage of $9 \%$ were unconform to the TGN parameter, and a number of 21 samples, representing a percentage of $13 \%$ were unconform to the parameter $\mathrm{Y}+\mathrm{M}$.

The most nonconformance were registered in the spaces intended to the receipt of raw material and milling of cereals, the number of samples with results over the tolerance values are of $13 \%$, respectively $18 \%$ in the case of TGN and of 18 , respectively $21 \%$ in the case of D+M.

By the suction method a number of 50 samples were sampled from the same area of the unit A and B spaces from which samples were sampled and by sedimentation as follows: Table 4.

Table 4. Number of samples by suction method

\begin{tabular}{|c|c|c|c|c|c|c|c|}
\hline No. & \multirow{2}{*}{$\begin{array}{c}\text { Denomination } \\
\text { of the unit }\end{array}$} & \multirow{2}{*}{$\begin{array}{c}\text { Total of } \\
\text { samples }\end{array}$} & & & \multicolumn{5}{|c|}{ Denomination of the space } \\
\cline { 5 - 9 } & & & $\begin{array}{c}\text { Receipt of raw } \\
\text { materials }\end{array}$ & Storage & Milling & Packaging & $\begin{array}{c}\text { Storage and } \\
\text { delivery }\end{array}$ \\
\hline 1. & A & 20 & 4 & 4 & 4 & 4 & 4 \\
\hline 2. & B & 30 & 6 & 6 & 6 & 6 & 6 \\
\hline & Total & 50 & 10 & 10 & 10 & 10 & 10 \\
\hline
\end{tabular}

To do the active monitoring we sampled a defined quantity of air, namely 100 liters $\left(0,1 \mathrm{~m}^{3}\right)$ using an equipment which allows the collection of air particles directly on a culture medium - DG 18, using devices

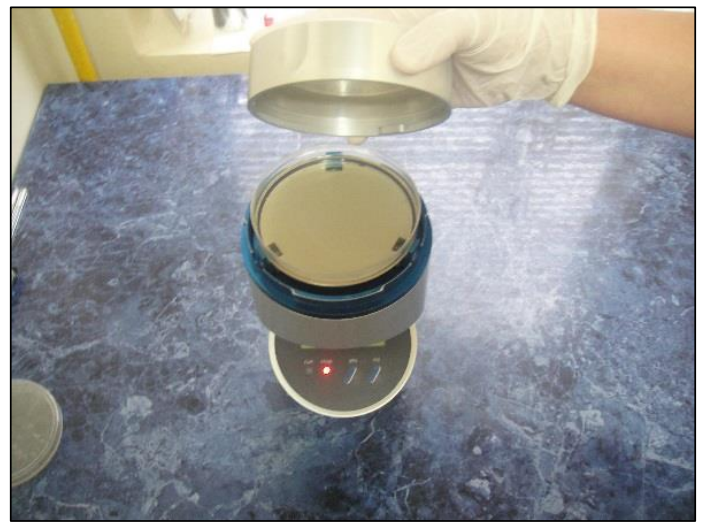

Figure 5. Equipment for sampling air (placing the Petri plate which contains culture medium) with separator, which allow the air to be pulled by a punctured plate (separator) with holes, with a known diameter and the particles are deposited on a plate with agar fixed underneath (Fig. 5 and 6).

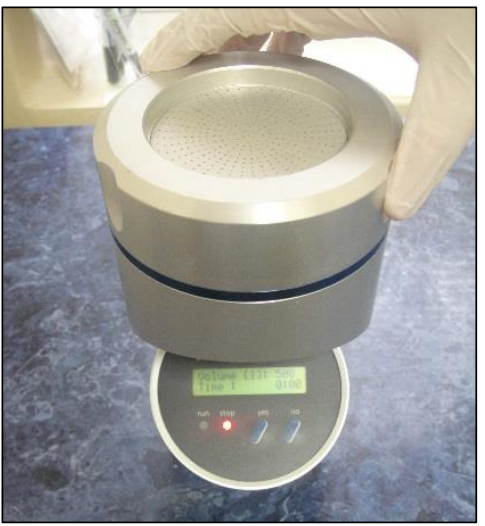

Figure 6. Equipment for sampling air (installation of site consecutively to the Petri plate) 
After sampling the plates were identified, packed, sealed and delivered to the laboratory, where they were incubated immediately after arrival at a temperature of $37^{\circ} \mathrm{C}$ in the case of $\mathrm{TNG}$ and $25^{\circ} \mathrm{C}$ in the case of $\mathrm{Y}+\mathrm{M}$. The incubation period was of 72 hours in the TGN case and 4-5 days in the $\mathrm{Y}+\mathrm{M}$ case, after incubation the culture media were examined to identify the eventual developed cultures (Fig. 7, 8, 9, 10).
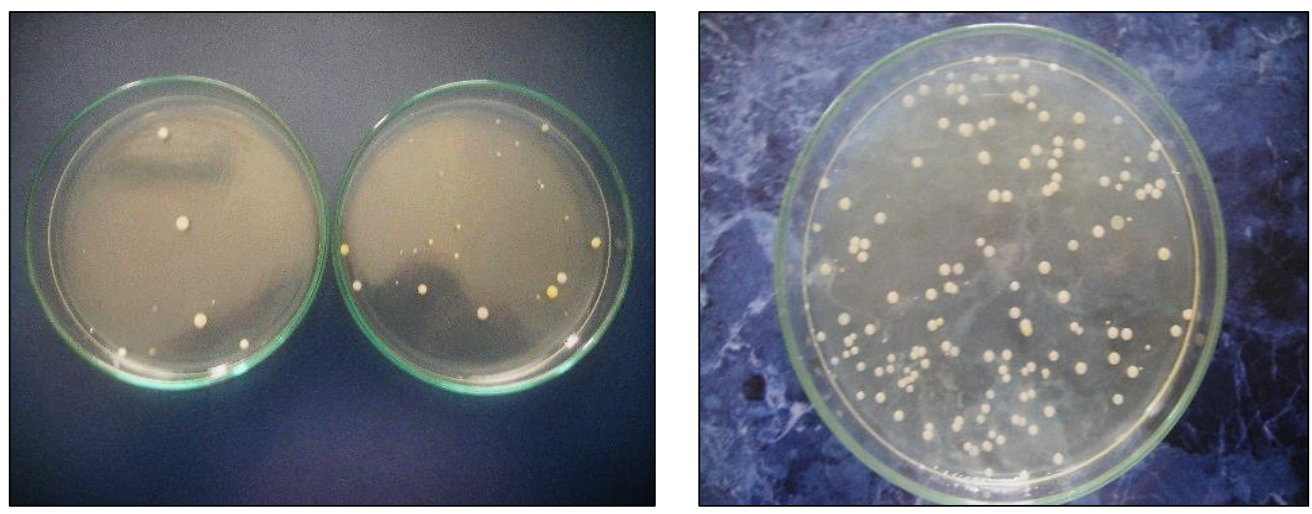

Figure 7 and 8. Petri plates with PCA - PCA culture medium
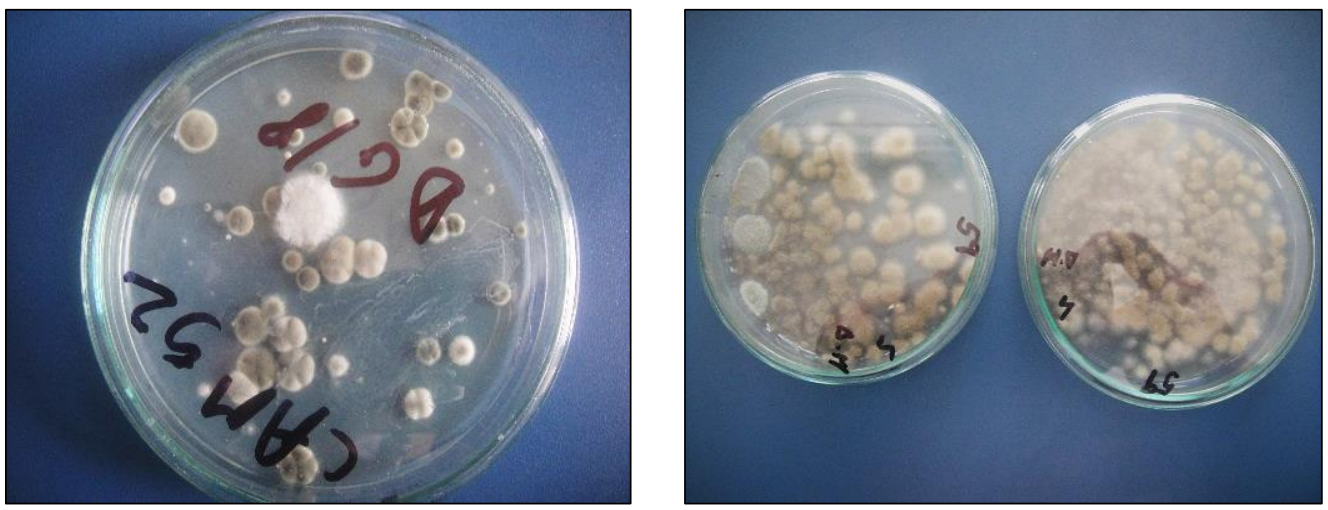

Figure 9 and 10. Petri plates with DG 18 culture medium

The total number of germs was calculated reporting the number of cultures developed on the surface of the culture medium to the air volume. The calculation method for the two methods is provided in the ISO $16000-17$ standard. "The interior air. part 17: detection and counting of molds - method based on cultivation." Pct. 7.6.2. method by impact.

- for each samples are analyzed in parallel two different volumes of air (ex. $1 \mathrm{~m}^{3}$ and $2 \mathrm{~m}^{3}$ ), being necessary 4 Petri plates for a sample;

- the concentration, expressed as $\mathrm{cfu} / \mathrm{m}^{3}$ of air, is calculated by the formula:

$$
\mathrm{C}_{\mathrm{I}}=\mathrm{n}_{\mathrm{cfu}} / \mathrm{V}_{\mathrm{I}}
$$

where:

$\mathrm{n}_{\mathrm{cfu}}=$ total number of colony forming units on the Petri plates

$\mathrm{V}_{\mathrm{I}}=$ total volume of the sample, in $\mathrm{m}^{3}$.

\section{Example:}

On the DG18 culture medium, a sample is analyzed for two different volumes of air of 100 liters and 200 liters.
At the counting, the following results were obtained: the volume of the sample of 100 liters $\left(0,1 \mathrm{~m}^{3}\right)$ - the number of developed cfu was of $34 \mathrm{cfu}$ in the plate 3 and $39 \mathrm{cfu}$ in the plate 4 .

$$
\begin{aligned}
& \mathrm{C}_{\mathrm{I}}=\mathrm{N}_{\mathrm{CFU}} / \mathrm{V}_{\mathrm{I}}=40 / 0,2=200=2,0 \times 10^{2} \\
& \mathrm{~N}_{\mathrm{CFU}}=21+19+34+39=113 \\
& \mathrm{~V}_{\mathrm{I}}=0,1+0,1+0,2+0,2=0,6 \\
& \mathrm{C}_{\mathrm{I}}=\mathrm{N}_{\mathrm{CFU}} / \mathrm{V}_{\mathrm{I}}=113 / 0,6=188=1,9 \times 10^{2}
\end{aligned}
$$

Taking into consideration the number of developed cfu on the surfaces of culture medium of the plates used for active monitoring and reporting them to the maximum approved values (The National Sanitary Veterinary and Food Safety Authority procedure), we considered out of line all the samples which presented values over $600 \mathrm{cfu} / \mathrm{m}^{3}$ in the case of TGN and over $300 \mathrm{cfu} / \mathrm{m}^{3}$ in the case of $\mathrm{Y}+\mathrm{M}$ (Table 2). 
In the case of TNG, the results were following: Table 5.

Table 5. Number of conform (C) and unconform samples (U)

\begin{tabular}{|c|c|c|c|c|c|c|c|c|c|c|c|c|c|c|c|c|c|c|}
\hline \multirow{4}{*}{$\begin{array}{l}\text { The name } \\
\text { of the unit }\end{array}$} & \multirow{2}{*}{\multicolumn{3}{|c|}{$\begin{array}{c}\text { Total number } \\
\text { of samples }\end{array}$}} & \multicolumn{15}{|c|}{ Denomination of space } \\
\hline & & & & \multicolumn{3}{|c|}{$\begin{array}{l}\text { Receipt of raw } \\
\text { materials }\end{array}$} & \multicolumn{3}{|c|}{ Storage } & \multicolumn{3}{|c|}{ Milling } & \multicolumn{3}{|c|}{ Packaging } & \multicolumn{3}{|c|}{$\begin{array}{c}\text { Storing and } \\
\text { delivery }\end{array}$} \\
\hline & \multirow{2}{*}{$\begin{array}{l}\mathrm{C} \\
\mathrm{No}\end{array}$} & \multicolumn{2}{|c|}{$\mathrm{U}$} & $\mathrm{C}$ & \multicolumn{2}{|c|}{$\mathrm{U}$} & $\mathrm{C}$ & \multicolumn{2}{|c|}{$\mathrm{U}$} & $\mathrm{C}$ & \multicolumn{2}{|c|}{$\mathrm{U}$} & $\mathrm{C}$ & \multicolumn{2}{|c|}{$\mathrm{U}$} & $\mathrm{C}$ & \multicolumn{2}{|c|}{$\mathrm{U}$} \\
\hline & & No & $\%$ & No & No & $\%$ & No & No & $\%$ & No & No & $\%$ & No & No & $\%$ & No & No & $\%$ \\
\hline A & 18 & 2 & 10 & 3 & 1 & 25 & 4 & - & - & 3 & 1 & 25 & 4 & - & - & 4 & - & - \\
\hline $\mathrm{B}$ & 26 & 4 & 13 & 5 & 1 & 17 & 6 & - & - & 5 & 1 & 17 & 5 & 1 & 17 & 5 & 1 & 17 \\
\hline Total & 44 & 6 & 12 & 8 & 2 & 20 & 10 & - & - & 8 & 2 & 20 & 9 & 1 & 10 & 9 & 1 & 10 \\
\hline
\end{tabular}

In the case of $\mathrm{Y}+\mathrm{M}$, the results were the following: Table 6.

Table 6. Number of conform (C) and unconform (U) samples

\begin{tabular}{|c|c|c|c|c|c|c|c|c|c|c|c|c|c|c|c|c|c|c|}
\hline \multirow{4}{*}{$\begin{array}{l}\text { The name } \\
\text { of the unit }\end{array}$} & \multirow{2}{*}{\multicolumn{3}{|c|}{$\begin{array}{l}\text { Total number } \\
\text { of samples }\end{array}$}} & \multicolumn{15}{|c|}{ Denomination of space } \\
\hline & & & & \multicolumn{3}{|c|}{$\begin{array}{l}\text { Receipt of raw } \\
\text { materials }\end{array}$} & \multicolumn{3}{|c|}{ Storage } & \multicolumn{3}{|c|}{ Milling } & \multicolumn{3}{|c|}{ Packaging } & \multicolumn{3}{|c|}{$\begin{array}{c}\text { Storing and } \\
\text { delivery }\end{array}$} \\
\hline & \multirow{2}{*}{$\frac{\mathrm{C}}{\mathrm{No}}$} & \multicolumn{2}{|c|}{$\mathrm{U}$} & $\mathrm{C}$ & \multicolumn{2}{|c|}{$\mathrm{U}$} & $\mathrm{C}$ & \multicolumn{2}{|c|}{$\mathrm{U}$} & $\mathrm{C}$ & \multicolumn{2}{|c|}{$\mathrm{U}$} & $\mathrm{C}$ & \multicolumn{2}{|c|}{$\mathrm{U}$} & $\mathrm{C}$ & \multicolumn{2}{|c|}{$\mathrm{U}$} \\
\hline & & No & $\%$ & No & No & $\%$ & No & No & $\%$ & No & No & $\%$ & No & No & $\%$ & No & No & $\%$ \\
\hline $\bar{A}$ & 17 & 3 & 10 & 3 & 1 & 25 & 4 & - & - & 3 & 1 & 25 & 3 & 1 & 25 & 4 & - & - \\
\hline $\mathrm{B}$ & 24 & 6 & 17 & 5 & 1 & 17 & 5 & 1 & 17 & 4 & 2 & 33 & 5 & 1 & 17 & 5 & 1 & 17 \\
\hline Total & 41 & 9 & 18 & 8 & 2 & 20 & 9 & 1 & 10 & 7 & 3 & 30 & 8 & 2 & 20 & 9 & 1 & 10 \\
\hline
\end{tabular}

It results that in the case of monitoring aeromicroflora by active monitoring, a number of 6 samples, representing a percentage of $12 \%$ were out of line at the TGN parameter, and a number of 9 samples, representing a percentage of $18 \%$ were unconform at the $\mathrm{Y}+\mathrm{M}$ parameter.

As in the case of passive monitoring, the most unconform were registered in the spaces intended the raw material receipt and grinding of cereals, the number of samples with results over the tolerance limits being of $20 \%$, in the case of TNG and of 20 , respectively $30 \%$, in the case of $\mathrm{Y}+\mathrm{M}$.

In the case of the out of line results the values obtained by us were ranging between $6,1 \times 10^{2}$ and $1,6 \times 10^{3} \mathrm{cfu} / \mathrm{m}^{3}$ in the case of TGN and $3,1 \times 10^{2}$ and $1,8 \times 10^{3} \mathrm{cfu} / \mathrm{m}^{3}$ in the case of $\mathrm{Y}+\mathrm{M}$.

Not identifying in the specialty literature the results of the aeromicroflora values in the milling and bread manufacturing units, we compared the results obtained by us with the results obtained in other types of spaces. So, in the cow farms of Romania, were obtained values ranging between maximum $2 \times 10^{3}$ and minimum $1,6 \times 10^{3} \mathrm{cfu} / \mathrm{m}^{3}$ in the case of cfu and $1,5 \times 10^{2}$ and $2,2 \times 10^{2} \mathrm{cfu} / \mathrm{m}^{3}$ in the case of $\mathrm{Y}+\mathrm{M}$ and in storage rooms for cattle slaughtering, $1018 \mathrm{cfu} / \mathrm{m}^{3}[7,8]$. In other countries, the study indicate the mean values of TGN of $1,7 \times 10^{3} \mathrm{cfu} / \mathrm{m}^{3}$ and $8,8 \times 10^{4} \mathrm{cfu} / \mathrm{m}^{3}$ or ranging between $2,82 \times 10^{4} \mathrm{cfu} / \mathrm{m}^{3}$ and $7,76 \times 10^{4} \mathrm{cfu} / \mathrm{m}^{3}$ [7].

The number of unconform samples in the milling and bread manufacturing units is bigger compared with the units of processing milk and milk products. In the units of milk processing, the passive monitoring allowed the identification of a number of $6 \%$ unconform samples, while the active monitoring of $13 \%$ the samples [4].

In laboratories, it was found that the microbiological loading of air differs depending on the season. So, TGN presented values between $1,8-0,03 \times 10^{3} \mathrm{cfu} / \mathrm{m}^{3}$ in the dry season and 8,0-0,01 x $10^{3} \mathrm{cfu} / \mathrm{m}^{3}$ in the wet season, and $\mathrm{Y}+\mathrm{M}$ presented values between $3,6-0,08 \times 10^{3} \mathrm{cfu} / \mathrm{m}^{3}$ in the dry season and $0,54-0,04 \times 10^{3} \mathrm{cfu} / \mathrm{m}^{3}$ in the wet season [6].

Performing a comparative analysis between the 2 types of monitoring, it results that the use of equipment which allow the sampling of some determined quantities of air, make possible a more efficient supervision, the number of out of line samples being bigger with $11 \%$ in the case of TGN and 13\% in the case of Y+M (Table 7). 
Table 7. Comparative analysis

\begin{tabular}{|c|c|c|c|c|c|}
\hline \multicolumn{2}{|c|}{ Passive monitoring } & \multicolumn{2}{c|}{ Active monitoring } & \multicolumn{2}{c|}{ Difference } \\
\hline $\begin{array}{c}\text { CFU } \\
\%\end{array}$ & Y+M & CFU & Y+M & CFU & Y \\
$\%$ & $\%$ & 3 & 6 \\
\hline 9 & 13 & 12 & 18 & 3 & 6 \\
\hline
\end{tabular}

Even if the number of out of line samples is significantly bigger in the case of active monitoring, we need to mention the fact that a passive monitoring offers important indices about the microbiological contamination or air in the milling and bread manufacturing units, the biggest number of noncompliance in both types of monitoring being registered approximatively at the same types of spaces, even if the values are different.

\section{Conclusion}

The passive monitoring of the aeromicroflora in milling and bread manufacture units allowed the detection of a number of out of line samples ranging between $9 \%-13 \%$, and the active monitoring of a number ranging between $12 \%-18 \%$. In the case of the out of line results the values obtained by us ranged between $6,1 \times 10^{2}$ and $1,6 \times 10^{3} \mathrm{cfu} / \mathrm{m}^{3}$ in the case of TGN and $3,1 \times 10^{2}$ and $1,8 \times 10^{3} \mathrm{cfu} / \mathrm{m}^{3}$ in the case of $\mathrm{Y}+\mathrm{M}$.

The most noncompliance was registered in the spaces intended to the receipt of raw materials and grinding cereals.

The monitoring of the aeromicroflora in the milling and bread manufacturing units offer important indices, representing the decisional base of implementing the corrective measures.

\section{References}

1. Bacterial Nomenclature up - to - date (Approved lists, validation lists). Compiled by Leibniz Institute DSMZ Deutsche Sammlung von Mikroornismen und Zellkulturen GmbH, Braunschweig, Germany (2012).

2. BÂRZOI D., APOSTU S. Food Microbiology. Risoprint Publishing House, Cluj-Napoca (2002).

3. MERAJ-UL-HAQUE, MOUSUMI BHOWAL \& APARNA PATIL. Diversity of Aeromycoflora in Indoor and Outdoor Environment. Imperial Journal of Interdisciplinary Research (IJIR) Vol-2, Issue-8, 2016 ISSN: 2454-1362, http://www.onlinejournal.in (2016).

4. PUCHIANU G., NECULA V., ENACHE D.V. Research on active and passive monitoring aeromicroflora in the milk units processing. Acadedemy of Romania Scientists, Annals - Series on Agriculture, Silviculture and Veterinary Medicine Sciences. Volume 5, Number 1, ISSN 2069/1149. Editura Academiei Oamenilor de Ştiinţă din România (2016).
5. RANALLI G., ZANARDINI E., SARTINI C. Biodeterioration - Including Cultural Heritige. Encyclopedia of Microbiology. Thid Edition. Volume 1. ISBN (online) 978-0-12-373944-5, www.elsevier.com (2009)

6. SHIAKA, G. PETER1, YAKUBU, S.E. Comparative Analysis of Airborne Microbial Concentrations in the Indoor Environment of Two Selected Clinical Laboratories. IOSR Journal of Pharmacy and Biological Sciences (IOSR-JPBS) e-ISSN: 2278-3008, p-ISSN:2319-7676. Volume 8, Issue 4 (Nov. - Dec. (2013), pp. 13-19 www.iosrjournals.org

7. TIŢA MIHAELA-ADRIANA, LETIŢIA, OPREAN, ECATERINA, LENGYEL, RAMONA MARIA IANCU, OVIDIU, TIŢA, CORINA SIMIAN. Studies concerning the hygiene conditions from the Sadu farm, Romania. Management of Sustainable Development Sibiu, Romania, Volume 6, No. 2 (2014)

8. TTIBULCĂ D., C. MAN, JIMBOREAN MIRELA, D. SĂLĂGEAN, E. RACOLŢA. Research concerning the aeromicroflora in work and storage rooms for cattle slaughtering. Bulletin USAMV-CN, 62/2006 (370-375) ISSN 1454-2383 (2006)

9. YASSIN M.F. ALMOUQATEA S. Assessment of airborne bacteria and fungi in an indoor and outdoor envirnment. Int. J. Environ Sci. Tech., 7 (3) 535-544 (2010).

10. Order of The National Veterinary Sanitary Authority and the Food Safety Authority, no. 35/2016. Methodological norms for the application of the program of actions for the supervision, prevention, control and eradication of animal diseases, animal transmission, animal protection and environmental protection, identification and registration of bovine, swine, ovine and goat for 2016 (ansvsa.ro).

11. ISO 16000-17. "The indoor air. Part 17: Detection and counting of molds - Method based on cultivation. Point 7.6.2 - impact method".

12. The National Veterinary Sanitary Authority and the Food Safety Authority procedure. Sampling of food samples for microbiological testing (ansvsa.ro).

13. SR EN ISO 4833-1 / 2009. Microbiology of the food chain. Horizontal method for enumeration of microorganisms. Part 1 . Colony Counting Technique at $30^{\circ} \mathrm{C}$ by Tile Plate Technique.

14. 13. SR ISO 21527-2: 2009. Microbiology of food and feed: Horizontal method for counting yeasts and molds. Part 2: Colony counting technique in products with water activity less than or equal to 0,95 .

15. https://biblioteca.regielive.ro/referate/biologie/microfloraaerului-232559.html 